\title{
SUKSESI VEGETASI PADA LAHAN BEKAS PENAMBANGAN EMAS RAKYAT DI KECAMATAN MONTERADO KABUPATEN BENGKAYANG
}

\author{
(Succession of vegetation on ex - community gold mining in Monterado Sub district, \\ Bengkayang Regency)
}

\author{
U. Nur Isnaniarti, Wiwik Ekyastuti, Hanna Artuti Ekamawanti \\ Fakultas Kehutanan, Universitan Tanjungpura Jl. Prof. Hadari Nawawi, Pontianak. 78121 \\ Email: isnaniarti@gmail.com
}

\begin{abstract}
This study aims to obtain information about the succession levels of natural vegetation on excommunity gold mining in Monterado. The method of this research was survey method through vegetation analysis by double plot size $20 \mathrm{~m} \times 20 \mathrm{~m}$. Placement of plots dileberately based on the tailing period of ex - community gold mining which were : < 1 year, 2-3 years, 5-7 years, and $>10$ years. The result showed that kinds of shrub found in all age level of ex-community gold mining area. The type of woody plants at the seedling found in all period of ex community gold mining area, whereas sapling, pole and tree only found in ex-community gold mining at age level > 10 years. Based on the vegetation analysis, it showed that Ischaemum rugosum and Melastoma malabathricum L. dominanted at all age level of ex - community gold mining. Seedling in the ex-community gold mining at all age level were dominanted by Dillenia suffruticus. The index of species diversity showed that it was still low on ex community gold mining in Monterado.Until the age of tailing > 10 years, succession was still in the level of competition, so it was concluded to be slow. To accelerate succession, revegetation, land restoration, and people awareness should be undertaken.
\end{abstract}

Keyword : community gold mining, Monterado Sub district, Succession

\section{PENDAHULUAN}

Kegiatan penambangan emas di dalam kawasan hutan merupakan salah satu gangguan terhadap hutan. Aktivitas penambangan emas dapat berdampak pada kondisi lingkungan baik secara fisik, kimia maupun biologi. Secara fisik dapat dilihat dari terbukanya lahan yang cukup luas dan berubah manjadi lahan tandus berwujud padang pasir berisi tailing. Secara kimiawi diketahui dari pencemaran air, tanah dan vegetasi akibat dari penggunaan zat yang berbahaya seperti merkuri. Secara biologi dapat dilihat dari hilangnya vegetasi dan asosiasi organisme.

Seiring dengan berjalannya waktu, lahan bekas penambangan emas akan mengalami suksesi. Kondisi lahan yang terbuka dan tandus perlahan-lahan akan ditumbuhi jenis-jenis pionir yang toleran terhadap kondisi lahan bekas penambangan emas yang miskin unsur hara. Hasil penelitian Roberto (2012) tentang studi tanaman pionir pada lahan bekas tambang emas rakyat di Cagar Alam Mandor, menunjukkan tingkat permudaan dan tumbuhan bawah yang bervariasi, baik dalam jumlah ataupun jenis pada areal bekas penambangan umur 1-3 tahun, 4-5 tahun, 6-10 tahun, dan 11-15 tahun.

Demikian halnya penambangan emas yang dilakukan di daerah Monterado telah mengakibatkan kerusakan yang menimbulkan pengaruh buruk terhadap kondisi lingkugan termasuk komposisi tegakan. Kondisi awal lahan yang baru 
ditinggalkan penambang berupa lahan terbuka dan tandus kemudian berubah seiring dengan perubahan waktu membentuk suatu ekosistem baru secara berangsur-angsur. Hal ini dapat dilihat dari keberadaan jenis vegetasi yang tumbuh pada lahan bekas penambangan dari beberapa rentang umur. Pada lahan yang baru ditinggalkan masih berupa lahan tandus, pada lahan yang berumur sekitar satu tahun tumbuh jenis rerumputan, dan pada lahan lebih dari 10 tahun jenis vegetasi yang tumbuh lebih beragam.

Pada areal bekas penambangan emas di Monterado, belum diketahui informasi tentang suksesi alaminya. Jenis tumbuhan apa saja yang berhasil tumbuh di areal tersebut, jenis-jenis apa saja yang mendominasi, keanekaragaman jenis tumbuhan yang ada, tingkat pertumbuhannya lengkap atau tidak, serta perbedaan komposisi jenis vegetasi di areal tersebut merupakan bagian dari masalah penelitian ini. Informasi suksesi alami vegetasi pada lahan bekas penambangan emas diperlukan untuk dijadikan dasar penanganan lanjutan. Berdasarkan survei awal pada lahan bekas penambangan emas di Kecamatan Monterado terdapat empat tingkatan umur tailing yang berbeda yaitu $<1$ tahun, 2-3 tahun, 5-7 tahun, dan > 10 tahun. Oleh karena itu, penelitian tentang suksesi lahan bekas penambangan emas di Monterado perlu dilakukan. Penelitian ini bertujuan untuk memperoleh informasi tentang tingkatan suksesi vegetasi alami yang terjadi pada areal bekas penambangan emas di Monterado.

METODE PENELITIAN Tempat dan Waktu
Penelitian ini dilakukan di areal bekas penambangan emas rakyat Kecamatan Monterado Kabupaten Bengkayang. Lama penelitian adalah 2 minggu di lapangan. Pada tanggal 25 April - 7 Mei 2016.

\section{Bahan dan Alat Penelitian}

Bahan yang dijadikan objek penelitian ini adalah semua vegetasi yang ditemukan dalam petak penelitian. Vegetasi tersebut dikelompokkan berdasarkan tingkat pertumbuhannya pada areal tailing yang telah berumur $<1$ tahun, 2 - 3 tahun, 5 - 7 tahun, dan $>10$ tahun. Pengelompokan umur areal bekas penambangan diperoleh dari informasi aparat desa sesuai dengan keadaan di lapangan.

Alat-alat yang digunakan dalam penelitian ini meliputi: Kompas, GPS, meteran dan tali, phiband, parang dan patok, kamera, tally sheet dan alat tulis menulis, buku pengenal pohon, alat dan bahan untuk membuat herbarium (gunting, ketas koran, label, dan alkohol), bor tanah, serta kantong plastik.

\section{Metode Penelitian}

Metode yang digunakan dalam penelitian ini adalah metode survei melalui analisis vegetasi dengan cara petak ganda dengan ukuran $20 \mathrm{~m}$ x $20 \mathrm{~m}$ yang didalamnya terdapat petak pengamatan sesuai tingkat pertumbuhan. Petak pengamatan $2 \mathrm{~m}$ x $2 \mathrm{~m}$ untuk pengamatan tumbuhan tingkat semai dan tumbuhan bawah, $5 \mathrm{~m}$ x $5 \mathrm{~m}$ untuk pengamatan tumbuhan tingkat pancang, $10 \mathrm{~m} \times 10 \mathrm{~m}$ untuk pengamatan tumbuhan tingkat tiang, $20 \mathrm{~m}$ x $20 \mathrm{~m}$ untuk pengamatan tumbuhan tingkat pohon. Pengenalan jenis tumbuhan dapat menggunakan bantuan kunci determinasi tanaman atau tenaga pengenal 
pohon setempat. Jika ditemukan jenis yang diragukan atau tidak diketahui jenisnya maka dibuat contoh herbarium tanaman tersebut untuk diidentifikasi.

Pengamatan sifat kimia tanah dilakukan pengambilan sampel tanah pada kedalaman 0-20 cm dari permukaan tanah dengan menggunakan bor tanah. Pada keempat areal lahan bekas penambangan, masing-masing diambil sampel tanah secara komposit sehingga diperoleh 4 sampel tanah. Selanjutnya sampel tersebut dianalisis di laboratorium tanah untuk mengetahui sifat kimia tanah seperti nitrogen, fosfor, dan C-organik.

\section{HASIL DAN PEMBAHASAN}

A. Jenis vegetasi dan komposisi jenis yang ditemukan pada setiap umur tailing.

Hasil pengamatan di lapangan, ditemukan jenis tumbuhan bawah dan jenis tumbuhan berkayu dari pertumbuhan tingkat semai, pancang, tiang dan pohon. Pada lahan bekas penambangan emas umur $<1$ tahun dibuat 5 petak pengamatan dengan luas total 0,002 ha ditemukan 18 jenis vegetasi terdiri dari 16 jenis tumbuhan bawah dengan jumlah individu 200 dan 2 jenis tumbuhan berkayu pada tingkat semai dengan jumlah individu 10 . Jenis-jenis tumbuhan bawah yang dominan di lokasi tersebut adalah alangalang, cengkodok, rumput jagu dan rumput ijuk, sedangkan jenis tumbuhan berkayu tersebut adalah simpur dan leban.

Pada lahan bekas penambangan emas umur 2-3 tahun dibuat 7 petak pengamatan dengan luas total 0,0028 ha ditemukan 15 jenis vegetasi terdiri dari 12 jenis tumbuhan bawah dengan jumlah individu
185 dan 3 jenis tumbuhan berkayu pada tingkat semai dengan jumlah individu 31 . Jenis-jenis tumbuhan bawah yang dominan di lokasi tersebut meliputi rumput jagu, alang-alang, cengkodok, dan rumput kerunong padi, sedangkan jenis tumbuhan berkayu meliputi simpur, kayu putih dan leban.

Pada lahan bekas penambangan emas umur 5-7 tahun dibuat 8 petak pengamatan dengan luas total 0,0032 ha ditemukan 13 jenis vegetasi terdiri dari 9 jenis tumbuhan bawah dengan jumlah individu 101 dan 4 jenis tumbuhan berkayu pada tingkat semai dengan jumlah individu 38. Jenisjenis tumbuhan bawah yang dominan di lokasi tersebut adalah rumput jagu, cengkodok dan rambangan, sedangkan jenis tumbuhan berkayu meliputi simpur, akasia daun lebar, obar-obar dan bengkutat.

Pada lahan bekas penambangan emas umur > 10 tahun dibuat 10 petak pengamatan dengan luas total 0,004 ha ditemukan 14 jenis vegetasi terdiri dari 6 jenis tumbuhan bawah dengan jumlah individu 101 dan 8 jenis tumbuhan berkayu dengan jumlah individu 97. Jenisjenis tumbuhan bawah yang dominan di lokasi tersebut meliputi rumput jagu, cengkodok, paku kawat dan kantong semar. Jenis tumbuhan berkayu pada tingkat semai meliputi simpur, leban, akasia daun lebar, obar-obar, rengas dan mahang, pada tingkat pancang yaitu jelutung, pada tingkat tiang yaitu akasia daun lebar dan akasia daun kedil, dan pada tingkat pohon yaitu akasia daun lebar. 
JURNAL TENGKAWANG (2017)

Vol. 7 (1) : 1 - 10

Tabel 1. Jenis vegetasi dan tumbuhan bawah yang ditemukan pada setiap umur tailing.

\begin{tabular}{|c|c|c|c|c|c|c|}
\hline \multirow{2}{*}{ No } & \multirow{2}{*}{ Nama lokal } & \multirow{2}{*}{ Nama ilmiah } & \multicolumn{4}{|c|}{$\begin{array}{l}\sum \text { individu yang ditemukan } \\
\text { pada setiap umur tailing }\end{array}$} \\
\hline & & & $\begin{array}{l}<1 \\
\text { thn }\end{array}$ & $\begin{array}{l}2-3 \\
\text { thn }\end{array}$ & $\begin{array}{l}5-7 \\
\text { thn }\end{array}$ & $>10$ thn \\
\hline 1 & Akasia daun kecil & $\begin{array}{l}\text { Acacia auriculiformis A. } \\
\text { Cunn. Ex Benth }\end{array}$ & - & - & - & 1 \\
\hline 2 & Akasia daun lebar & Acacia mangium Willd. & - & - & 8 & 3 \\
\hline 3 & Alang-alang & Imperata cylindrica & 63 & 34 & 6 & - \\
\hline 4 & Bengkutat & Ilex cymosa $\mathrm{B} 1$. & - & - & 5 & - \\
\hline 5 & Cengkodok & $\begin{array}{l}\text { Melastoma malabathricum } \\
\text { L. }\end{array}$ & 21 & 18 & 9 & 88 \\
\hline 6 & Jelutung & $\begin{array}{l}\text { Dyera costulata (Miq). } \\
\text { Hook. F., J. Linn. }\end{array}$ & - & - & - & 2 \\
\hline 7 & Kalopo & $\begin{array}{l}\text { Calopogonium mucunoides } \\
\text { Desv }\end{array}$ & 4 & - & - & - \\
\hline 8 & Kancing lurah & $\begin{array}{l}\text { Centratheum punctatum } \\
\text { Cass }\end{array}$ & 8 & - & - & - \\
\hline 9 & Kayu putih & Melaleuca leucandendra $\mathrm{L}$ & - & 8 & - & - \\
\hline 10 & Krangkong & Ludwigia sp & 2 & & - & - \\
\hline 11 & Leban & Vitex pinnata $\mathrm{L}$ & 1 & 2 & - & 25 \\
\hline 12 & Mahang & $\begin{array}{l}\text { Endospermum diadenum } \\
\text { (Miq). Airy Shaw, Kew } \\
\text { Bull. }\end{array}$ & - & - & - & 1 \\
\hline 13 & Kantong semar & Nepenthes sp & - & - & - & 16 \\
\hline 14 & Obar-obar & Glochidion littorale Blume & - & - & 6 & 6 \\
\hline 15 & Pakis & Stenochlaena palustris & - & - & 5 & - \\
\hline 16 & Paku kawat & Lycopodium cernuиm L. & 18 & 5 & 4 & 24 \\
\hline 17 & Paku-pakuan & Blechnum finlaysonianum & 1 & & - & 1 \\
\hline 18 & Purun & Eleoccharis dulcis & 1 & 13 & - & - \\
\hline 19 & Rambangan & Scleria bacana & - & 4 & 12 & - \\
\hline 20 & Rengas & Gluta sp & - & - & - & 5 \\
\hline 21 & Resam & Dicranopteris linearis & 13 & 11 & 18 & - \\
\hline 22 & $\begin{array}{l}\text { Rumput batang } \\
\text { pjg }\end{array}$ & Eragrostis atrovirens & 1 & 3 & - & - \\
\hline 23 & Rumput ijuk & Eleoccharis geniculata L. & 19 & 12 & 3 & 1 \\
\hline 24 & Rumput jagu & Ischaemum rugosum & 24 & 46 & 35 & 97 \\
\hline 25 & $\begin{array}{l}\text { Rumput kerunong } \\
\text { padi }\end{array}$ & Panicum repens & 12 & 24 & 9 & - \\
\hline 26 & Rumput payungan & Cyperus difformis $\mathrm{L}$. & 1 & 7 & - & - \\
\hline 27 & Rumput peking & Eragrotis unioloides & - & 8 & - & - \\
\hline 28 & Rumput teki & Kyllinga polyphylla & 11 & - & - & - \\
\hline 29 & Simpur air & Dillenia suffruticosa (Giff). & 9 & 21 & 19 & 51 \\
\hline 30 & Sosa & Cyperus javanicus & 1 & - & - & - \\
\hline & $\sum$ jenis $\mathrm{y}$ & ng ditemukan & 18 & 15 & 13 & 14 \\
\hline
\end{tabular}

Sumber: Analisis Data 2016 
Jenis tumbuhan bawah yang
ditemukan pada lahan bekas penambangan emas umur $<1$ tahun, 2-3 tahun, dan > 10 tahun hampir sama seperti cengkodok, rumput jagu, paku kawat, rumput ijuk. Ditemukan pula jenis kantong semar yang baru hadir pada lahan bekas penambangan emas umur > 10 tahun. Pada lahan bekas penambangan emas umur $>10$ tahun jenis alang-alang mulai menghilang.

Jenis tumbuhan berkayu tingkat semai ditemukan pada semua umur lahan bekas penambangan, sedangkan untuk tingkat pancang, tiang, dan pohon hanya ditemukan pada lahan bekas penambangan emas umur $>10$ tahun. Jenis tumbuhan berkayu yang ditemukan pada tingkat pancang, tiang, dan pohon jumlahnya masih sangat sedikit. Sama halnya dengan penelitian yang dilakukan Roberto (2012) pada areal bekas penambangan emas di Mandor vegetasi tingkat pohon baru ditemukan pada umur lahan $>10$ tahun.

B. Indeks dominansi jenis $(\mathrm{C})$, indeks keanekaragaman jenis ( $\left.\mathrm{H}^{\prime}\right)$, dan indeks kelimpahan jenis (e) untuk masing-masing tingkat pertumbuhan pada lahan bekas penambangan emas yang berbeda umur.

Tabel 2. Nilai indeks dominansi, indeks keanekaragaman jenis, dan indeks kelimpahan jenis untuk masing-masing tingkat pertumbuhan vegetasi pada umur lahan yang berbeda.

\begin{tabular}{clccc}
\hline $\begin{array}{c}\text { Tingkat } \\
\text { Pertumbuhan }\end{array}$ & Umur lahan & C & $\mathrm{H}^{\prime}$ & $\mathrm{e}$ \\
\hline Tumbuhan & $<1$ tahun & 0,15 & 0,94 & 0,79 \\
bawah & $2-3$ tahun & 0,14 & 0,95 & 0,88 \\
& $5-7$ tahun & 0,19 & 0,83 & 0,87 \\
& $>10$ tahun & 0,31 & 0,59 & 0,76 \\
Semai & $<1$ tahun & 0,82 & 0,14 & 0,47 \\
& $2-3$ tahun & 0,53 & 0,34 & 0,72 \\
& $5-7$ tahun & 0,34 & 0,53 & 0,89 \\
\multirow{5}{*}{ Pancang } & $>10$ tahun & 0,39 & 0,51 & 0,66 \\
& $<1$ tahun & - & - & - \\
& $2-3$ tahun & - & - & - \\
& $5-7$ tahun & - & - & - \\
& $>10$ tahun & 1 & 0 & 0 \\
& $<1$ tahun & - & - & - \\
& $2-3$ tahun & - & - & - \\
& $5-7$ tahun & - & - & 1 \\
& $>10$ tahun & 0,5 & 0,30 & - \\
& $<1$ tahun & - & - & - \\
& $2-3$ tahun & - & - & - \\
& $5-7$ tahun & - & 0 & 0 \\
& $>10$ tahun & 1 & & - \\
\hline
\end{tabular}

Sumber: Analisis data 2016 
Hasil perhitungan indeks dominansi jenis, indeks keanekaragaman jenis, dan indeks kelimpahan jenis untuk masingmasing tingkat pertumbuhan pada lahan bekas penambangan emas yang berbeda umur dapat dilihat pada Tabel 2. Hasil perhitungan memberikan gambaran perbedaan nilai indeks dominansi, indeks keanekaragaman, dan indeks kelimpahan jenis dari setiap tingkat pertumbuhan.

Dilihat dari nilai indeks dominasi menggambarkan bahwa tumbuhan bawah, semai, pancang tiang dan pohon mendominasi lahan bekas penambangan emas umur $>10$ tahun. Jenis rumput jagu dan jenis cengkodok ditemukan mendominasi pada setiap lahan bekas penambangan emas. Jenis kantong semar baru hadir pada lahan bekas penambangan emas dan ikut mendominasi lahan bekas penambangan emas umur $>10$ tahun. Tumbuhan bekayu tingkat semai pada lahan bekas penambangan emas umur $<1$ tahun, 2-3 tahun, 5-7 tahun dan $>10$ tahun memiliki persamaan jenis yang dominan yaitu jenis simpur air. Hal yang sama juga ditemukan Roberto (2012) pada lahan bekas penambangan emas di Kecamatan Mandor yang menyatakan bahwa simpur air merupakan jenis tanaman yang dapat tumbuh pada lahan bekas penambangan emas. Merdekawati dkk. (2004) mengemukakan bahwa tumbuhan simpur air (Dillenia suffruticosa (Giff).) merupakan tumbuhan adaptif yang mampu tumbuh pada lahan terbuka dan memiliki tingkat toleransi yang tinggi terhadap merkuri $(\mathrm{Hg})$.
Vegetasi tingkat pancang, tiang dan pohon hanya ditemukan pada lahan bekas penambangan emas umur $>10$ tahun. Vegetasi tingkat pancang di dominansi oleh jelutung, vegetasi tingkat tiang di dominansi oleh akasia daun lebar dan akasia daun kecil, sedangkan vegetasi tingkat pohon didominansi oleh akasia daun lebar.

Dari hasil perhitungan nilai indeks keanekaragaman jenis pada setiap umur lahan bekas penambangan dari masing masing tingkat pertumbuhan, nilai tertinggi yaitu 0,95 . Indeks keanekaragaman jenis ( $\left.\mathrm{H}^{\prime}\right)$ menurut Shannon-Wienner (1963), jika nilai H' < 1 menunjukkan bahwa keanekaragaman jenis pada suatu transek adalah sedikit atau rendah. Berdasarkan nilai indeks keanekaragaman jenis menunjukkan bahwa keanekaragaman jenis pada lahan bekas penambangan emas di Monterado masih sedikit atau rendah. Rendahnya keanekaragaman jenis dikarenakan kondisi lahan bekas penambangan emas yang miskin hara, sehingga hanya jenis yang adaptif saja yang mampu tumbuh pada kondisi lahan yang miskin hara.

Berdasarkan hasil analisis tanah kandungan $\mathrm{N}, \mathrm{P}$ dan $\mathrm{C}$ lahan bekas penambangan emas di Monterado termasuk dalam kriteria kesuburan tanah yang sangat rendah. Tjhiaw dan Djohan (2009) mengemukakan bahwa miskinnya hara pada lahan bekas lahan penambangan emas membuat hanya jenis yang adaptif yang mampu bertahan hidup. 
Jenis cengkodok ditemukan pada semua umur lahan bekas penambangan emas. Cengkodok dinilai adaptif karena mampu bertahan pada kondisi tanah yang miskin hara (Tjhiaw dan Djohan, 2009). Menurut Suhardi (2008), cengkodok dapat memperbaiki kandungan hara tanah dengan menurunkan kemasaman tanah. Selain cengkodok, kantong semar yang muncul pada lahan bekas penambangan emas umur >10 tahun. Kantong semar menjadi indikator miskinnya hara pada lahan bekas penambangan emas (Tjhiaw dan Djohan, 2009).

C. Indek kesamaan.

Lahan bekas penambangan emas yang berumur 2-3 tahun dengan 5-7 tahun memiliki nilai indeks kesamaan yang tinggi yaitu 0,86 (Tabel.3). Jika nilai indeks kesamaan komunitas $>0,5$ berarti jenis yang dibandingkan sama antara dua lokasi, jika nilai indeks kesamaan komunitas < 0,5 berarti jenis yang dibandingkan berbeda antara dua lokasi (Sorensen, 1948 dalam Odum, 1996). Berdasarkan hasil analisis menunjukkan bahwa komunitas tumbuhan bawah pada lahan 2-3 tahun dengan 5-7; lahan < 1 tahun dengan 2-3 tahun dan lahan $<1$ tahun dengan 5-7 tahun dapat dikatakan relatif sama. Hal ini terjadi karena belum ada perubahan komunitas secara ekstrim, sehingga komunitas yang ditemukan masih relatif sama.

Tabel 3. Nilai indeks kesamaan komunitas tumbuhan bawah pada lahan bekas penambangan emas.

\begin{tabular}{lc}
\hline \multicolumn{1}{c}{ Umur Lahan Yang Dibandingkan } & Indeks Kesamaan Komunitas (\%) \\
\hline Umur $<1$ tahun dg 2-3 tahun & 0,71 \\
Umur $<1$ tahun dg 5-7 tahun & 0,56 \\
Umur $<1$ tahun dg $>10$ tahun & 0,45 \\
Umur 2-3 tahun dg 5-7 tahun & 0,86 \\
Umur 2-3 tahun dg > 10 tahun & 0,44 \\
Umur 5-7 tahun dg $>10$ tahun & 0,53 \\
\hline Sumber: Analisis data 2016 &
\end{tabular}

Tabel 4. Nilai indeks kesamaan komunitas vegetasi tingkat semai, pancang, tiang dan pohon pada lahan bekas penambangan emas.

\begin{tabular}{lcccc}
\hline \multirow{2}{*}{$\begin{array}{c}\text { Umur Lahan yang } \\
\text { Dibandingkan }\end{array}$} & \multicolumn{3}{c}{ Indeks Kesamaan Komunitas (\%) } \\
\cline { 2 - 5 } & Semai & Pancang & Tiang & Pohon \\
\hline Umur <1 tahun dg 2-3 tahun & 0,80 & 0 & 0 & 0 \\
Umur <1 tahun dg 5-7 tahun & 0,33 & 0 & 0 & 0 \\
Umur <1 tahun dg > 10 tahun & 0,50 & 0 & 0 & 0 \\
Umur 2-3 tahun dg 5-7 tahun & 0,29 & 0 & 0 & 0 \\
Umur 2-3 tahun dg > 10 tahun & 0,44 & 0 & 0 & 0 \\
Umur 5-7 tahun dg > 10 tahun & 0,60 & 0 & 0 & 0 \\
\hline
\end{tabular}

Sumber : Analisis data 2016 
Data Tabel.4 menunjukkan bahwa tingkat kesamaan komunitas vegetasi tingkat semai pada lahan bekas penambangan emas yang dibandingkan antara umur $<1$ tahun dengan 2-3 tahun memiliki nilai indeks kesamaan yang tinggi yaitu 0,80 . Hal ini menunjukkan bahwa vegetasi tingkat semai pada lahan bekas penambangan emas umur < 1 tahun dengan umur 2-3 tahun memiliki kesamaan. Sementara, untuk tingkat pancang, tiang dan pohon tidak memiliki kesamaan karena vegetasi tingkat semai, pancang, tiang dan pohon hanya ditemukan pada satu umur saja yaitu $>10$ tahun.

Komunitas tumbuhan pada tingkat semai pada lahan bekas penambangan emas umur $<1$ tahun dengan 2-3 tahun dapat dikatakan relatif sama, kemudian lahan bekas penambangan emas umur < 1 tahun dengan 5-7 tahun, 1 tahun dengan > 10 tahun, 2-3 tahun dan 5-7 tahun dan 2-3 tahun dengan $>10$ tahun memiliki nilai indeks kesamaan kurang dari 0,5. Hal ini menunjukkan bahwa komunitasnya dapat dikatakan berbeda, karena sudah ada perubahan jenis-jenis yang ditemukan. Hal ini dapat dilihat dari jenis tumbuhan pada tingkat semai yang ditemukan pada lahan bekas penambangan emas umur $<1$ tahun hanya 2 jenis tumbuhan, sedangkan pada umur $>10$ tahun sudah ditemukan 6 jenis tumbuhan. Perbedaan nya pada penambahan jumlah jenis yang ditemukan pada lahan umur $>10$ tahun. Komunitas tingkat pancang, tiang, pohon karana hanya ditemukan pada lahan bekas penambangan umur $>10$ tahun. Nilai indeks kesamaan nya tidak dihitung, karena tidak memiliki indeks kesamaan dengan lahan bekas penambangan emas yang lainnya.

D. Suksesi

Pada lahan bekas penambangan emas di Monterado suksesi yang terjadi secara alami. Keadaan awal berupa hutan sekunder yang kemudian menjadi hamparan pasir akibat dari penambangan emas. Seiring dengan berjalannya waktu, lahan yang berupa hamparan pasir perlahan-lahan ditumbuhi oleh rumput atau tumbuhan pionir. Sastroutomo (1990) mengemukakan bahwa suksesi sekunder merupakan pola perubahan suatu vegetasi akibat adanya gangguan lingkungan, yang menyebabkan daerah ini tidak bervegetasi untuk kemudian ditumbuhi kembali secara perlahanlahan.

Suksesi vegetasi pada lahan bekas penambangan emas di Monterado jika mengacu pada Clement (1974) sudah mencapai tahap kompetisi, yaitu persaingan sehingga ada pergantian spesies satu dengan spesies lainnya. Pergantian jenis dapat dilihat dari jenis tumbuhan yang ditemukan pada setiap lahan bekas penambangan emas. Odum (1971) mengemukakan bahwa komunitas untuk mencapai klimaks akan bervariasi dalam ekosistem yang berbeda. Selanjutnya dikatakan bahwa adanya pergantian komunitas cenderung untuk mengubah lingkungan fisik, sehingga menjadi habitat yang cocok untuk komunitas lain sampai keseimbangan biotik tercapai.

Beberapa jenis tumbuhan bawah yang ditemukan pada lahan bekas 
penambangan emas umur $<1$ tahun tidak ditemukan lagi pada umur $>10$ tahun. Seperti jenis alang-alang yang ditemukan pada umur lahan $<1$ tahun, berkurang jumlah jenis nya pada umur 5-7 tahun, kemudian hilang keberadaannya pada umur $>10$ tahun. Hilangnya jenis alang-alang pada lahan bekas penambangan emas umur $>10$ tahun kemudian digantikan dengan kehadiran jenis kantong semar.

Soerianegara dan Indrawan (1988) menyatakan jika hutan hujan mengalami kerusakan oleh alam atau manusia maka suksesi sekunder yang terjadi biasanya dimulai dengan vegetasi rumput dan semak. Jika keadaan tanah tidak banyak mengalami kerusakan, maka sesudah 15-20 tahun terjadi hutan sekunder muda, dan sesudah 50 tahun terjadi hutan sekunder tua yang secara berangsur angsur akan mencapai klimaks. Ramli (1989) mengemukakan studi tentang suksesi sekunder menunjukkan bahwa perkembangan suatu klimaks akan berlangsung kira-kira 200 tahun. Suksesi yang terjadi pada lahan bekas penambangan emas di Monterado berlangsung lambat. Hal ini dapat dilihat dari jenis yang ditemukan pada tingkat pancang tiang dan pohon pada umur lahan > 10 tahun masih sedikit. Sama halnya dengan suksesi pada lahan bekas penambangan timah, Nurthjahya (2008) dalam penelitiannya menyatakan bahwa suksesi pada lahan bekas penambangan timah berjalan sangat lambat. Dapat disimpulkan bahwa lahan bekas penambangan mengalami banyak kerusakan, sehingga suksesi alami pada lahan bekas penambangan berjalan sangat lambat untuk kembali klimaks.

Akibat kegiatan penambangan membuat tanah menjadi marginal, sehingga sangat miskin unsur hara dan bahan organik. Finegan (1992) dalam Irwanto (2006) menyatakan kesuburan tanah merupakan faktor ekologi yang penting untuk sukesi. Suksesi berjalan jauh lebih lambat pada tanah-tanah yang miskin unsur hara daripada tanah yang kaya unsur hara. Pada tanah-tanah yang miskin akan unsur hara, kolonisasi jenis-jenis pionir awal membutuhkan waktu puluhan tahun lamanya dan terjadi dengan sangat tidak teratur (Irwanto, 2006).

\section{KESIMPULAN}

Dari hasil penelitian yang dilakukan pada lahan bekas penambangan emas di Kecamatan Monterado dapat disimpulkan sebagai berikut:

1. Suksesi yang terjadi pada lahan bekas penambangan emas di Kecamatan Monterado berjalan lambat. Sampai umur > 10 tahun keanekaragaman jenis yang ada masih sedikit atau rendah. Vegetasi pada tingkat pohon baru ditemukan pada lahan bekas penambangan emas umur $>10$ tahun dengan jumlah yang sedikit.

2. Lahan bekas penambangan emas di Kecamatan Monterado suksesi sekunder yang terjadi telah mencapai tahap kompetisi, yaitu persaingan sehingga ada pergantian spesies satu dengan spesies lainnya.

\section{DAFTAR PUSTAKA}


Clement, F.C. 1974. Plant Succesion on Degrade Land in Singapore. Journal of Tropical Forest Science 4 (2). Department of Botani. University of Hongkong. Hongkong.

Irwanto. 2006. Dinamika dan Pertumbuhan Hutan Sekunder.Yogyakarta : Gadjah Mada University Press

Merdekawati, L., Burhanudin, Dewantara, I. 2004. Kemampuan Empat Jenis Tanaman Dalam Menyerap Cemaran Merkuri Di Media Tailing. [Skripsi] Universitas Tanjungpura.

Nurthjahya, E. 2008. Revegetasi Lahan Pasca Tambang Timah Dengan Beragam Jenis Pohon Lokal Di Pulau Bangka. [Tesis] Bogor: Sekolah Pasca Sarjana, Institut Pertanian Bogor.

Odum, E.P. 1971. Fundamentals of Ecology. W.B Sanders Company. Philadeliphia-London-Toronto.

Odum, E.P. 1996. Dasar-dasar ekologi (T. Samingan, Terjemahan). Yogyakarta: Gadjah Mada University Press.
Ramli, D. 1989. Ekologi. Jakarta: Departemen Pendidikan dan Kebudayaan.

Roberto, R., 2012. Studi Tanaman Pionir Pada Lahan Bekas Penambangan Emas Rakyat di Cagar Alam Mandor Kabupaten Landak, Skripsi Fakultas Kehutanan. UNTAN. Pontianak.

Sastroutomo, S., 1990. Ekologi Gulma, PT. Gramedia Utama Pustaka, Jakarta.

Shannon, C. H. and Weaner W., 1963, The Mathematical Theory of Communication, University of Illinois Press, Urbana.

Sorianegara, I., dan A. Indrawan, 1988. Ekologi Hutan Indonesia, Fakultas Kehutanan Institut Pertanian Bogor, Bogor.

Suhardi. 2008. The Role Melastoma malabathricum L. As Alumminium Acumulator Plant to Phosphorous Availbility on Ultisol Soil. Fakulatas Pertanian UNIB.

Tjhiaw, G. dan Djohan, T.S. 2009. Suksesi Vegetasi Alami Di Bekas Tambang Timah Pulau Bangka. Fakultas Biologi. Universitas Gajah Mada. Yogyakarta. 